\title{
Implementation of total quality management in cheap packages education Program in Community Learning Activity Center (PKBM) Maju Jaya Mesuji district lampung Indonesia
}

\author{
M Sururi $^{1}$, M.Ihsan Dacholfany ${ }^{2}$ \\ ${ }^{1,2}$ University Muhammadiyah Metro Lampung, Indonesia \\ Email:Msururi11@yahoo.com,mihsandacholfany@yahoo.com
}

\begin{abstract}
Quality management is something that needs to be prepared in improving human resources in the coming era. Pursuing an education package is one of the solutions in overcoming the equal distribution of education to improve the quality of Indonesian human resources. The quality of pursuing education packages must also be prepared to carry out quality education. The quality of pursuing education packages can be implemented by fulfilling four aspects, namely aspects of leadership, aspects of the quality of educators, aspects of service quality and aspects of customer satisfaction. The synergy of the four aspects is the key to the success of a quality education that is well realized
\end{abstract}

Keywords: management, education, Indonesia, human resources, solutions.

\section{PRILIMINARY}

Education is an internal part of the development of a nation because education is a place to improve and develop the human resources needed in the nation's development process. To achieve this we need an education that must be managed professionally. National education is a conscious and planned effort to create an atmosphere of learning and learning process so that students can effectively develop their potential both spiritually, self-control, intelligence and skills for those needed for themselves, society and the State (Law Number 20 Year 2013).

The development of science and technology has brought changes in almost all aspects of human life. Various problems can only be solved except by mastering and improving science and technology. In addition to the benefits of human life, on the one hand, these changes have also brought people into an era of increasingly fierce global competition. To be able to play a role in global competition, then as a nation we need to continue to develop and improve the quality of its human resources. Improving the quality of human resources is a necessity that must be carried out in a planned, directed, intensive, effective and efficient manner in the development process, if we do not want this nation to lose in competition in the current era of globalization, thus Education has an important role in development programs, thus determining the success of development.(M. Ihsan Dacholfany, 2018)

In terms of quantity, Indonesia's education is progressing very rapidly, but in terms of quality, its development is still uneven. This is proven by the large number of educational disparities in eastern Indonesia and western Indonesia. The quality of education should be able to be evenly distributed in terms of implementation. Education carried out by a school will produce good results if it has a quality process. For this reason, it is necessary to renew the quality of education in the sense that educational outcomes must be able to produce quality human beings (M. Ihsan Dacholfany, 2016: 18)

The meaning of quality itself is "a dynamic condition related to products, services, people, processes, and the environment that meets or exceeds expectations". In the field of education, "the quality of education is comprehensive, involves all components, implementers, and activities that exist in education and is referred to as Total Quality". Quality educational outcomes will not be achieved if only with one component and quality activities, because educational activities are quite complex. A component, an activity, an actor, are related to and need support from another activity and component dan can implemented in accordance with the objectives and demands of th stakeholders or markets (Widhiya Ninsiana and M.Ihsan Dacholfany (2017: 332) 
The low quality of education in Indonesia is inseparable from the complexity of the problems of education in Indonesia. One of the factors causing the low education of the majority of Indonesian people is the marginalized education system due to the unstable condition of educational equality which is still not well implemented. Through a long thought, it was found that so far there is a discrepancy in educational goals so that finally the strength of graduates has a lower level than the countries around Indonesia. Seeing from this phenomenon, Indonesian education should immediately improve, especially now that Indonesia is part of the ASEAN Economic Community (AEC) treaty agreement or commonly known as the ASEAN free market period.

In the future, the AEC is an opportunity for Indonesia with all the potential available, but on the other hand, it will also become a weapon that will make Indonesia a guest in its own country. This can happen if in terms of HR in Indonesia is still lagging behind the AEC member countries. In the MEA it is stated that every human resource in an MEA member country is allowed to seek employment opportunities freely to other MEA member countries. Of course, this phenomenon must be able to handle it well, the solution to improve it is through improving the quality of human resources in Indonesia through education. As the authors stated above, the current problematics are still lacking in educational equity.

The current condition of Indonesia is that there are still many human resources with low levels of education. Even in the eastern regions of Indonesia, there are still many who have not yet received an education, this is certainly a homework of the Indonesian government to implement educational equalization to make qualified Indonesian human resources capable of competing with other nations in the face of increasingly fierce competition in the future. One form or step that can improve the improvement of the quality of Indonesian human resources is by increasing the qualification of Indonesian community school graduation levels. It is undeniable that the high and low levels of school graduation qualifications affect the workforce. Meanwhile, foreign competitors will come to Indonesia with all the high quality and graduation qualifications. The solution to these problems can be accommodated, one of which is by equalizing the level of qualification of human resources in Indonesia or better known as chasing the package, in addition to improving their quality and standard of living and obtaining relevant skills that can be used to make a living so that citizens have a mental attitude of renewal and development for progress and development in a country.(M. Ihsan Dacholfany, 2018: 43)

This equality education is an activity that can be carried out in non-school education as a nonformal education sub-system. Non-formal education is an education that is organized consciously but does not follow strict and strict rules. Given the definition of understanding, non-formal education is between formal education and informal education.

Equality Education is one of the education units in the non-formal education pathway that includes study groups (chasing) Package A Programs equivalent to elementary school / junior high school, Package B Programs equivalent to junior high school, and Package $C$ Programs equivalent to high school which can be held through Learning Centers ( SKB), Community Learning Activity Center (PKBM), or other similar units. Law No. 20 of 2003 concerning the National education system states that the education pathway consists of formal, non-formal and informal education that can complement and replace each other.

Regarding the above, one of the efforts taken to expand access to education to support lifelong education is through equality education. Equivalence education is a non-formal education program that organizes general education which includes Package A (equivalent to elementary school), Package B (equivalent to junior high school,) and Package $\mathrm{C}$ (equivalent to high school). The chase package program certainly cannot be separated from integrated quality management in carrying out learning activities and other supporting activities. What's more, the pursuit of an education package is one solution in improving the quality of students. That is because a good or bad system will affect its output, namely students. Nowadays, chasing a package is something that helps in overcoming all problems in improving the quality of human resources in Indonesia, especially in the qualifications of students' graduates. In this study, the authors wish to examine more deeply about Total Quality Management in the pursuit of packages A, B, and C or equivalent to elementary school / junior high school / high school. Students who take part in this program can then take the National Education Equivalency Examination (UNPK) whose graduation certificate is recognized as being equivalent to a formal school diploma from basic education to senior secondary education.

The research location that the writer chose was The center of teaching and learning activities (PKBM) Maju Jayadan PKBM Maju Jaya, both located in Malang Regency and Malang City. The author conducted this research at institutions that focus on the same educational services, namely services in the field of equalizing graduate qualifications. The study was conducted in two institutions located in two different cities with a distance that is not so far between the two institutions, the researchers intend to do so because of this research it is expected to know the similarities or differences between the two 
institutions. Moreover, the location of the two institutions is in a big city, which requires its people to have high quality.

This research is expected to be able to illustrate the quality of the package pursuit program, which is currently in the general public is still seen as an instant school to get a diploma. So that this research hopes to become a medium of information for the public regarding the pursuit of the package because the quality of a program can be said to be good or not. Then from the various explanations above, the researcher will raise the research with the title "Implementation of Total Quality Management in the pursuit of a multi-site study program in Community Learning Activity Center (PKBM).

\section{METHOD}

Researchers will examine based on four focuses, namely (1) the role of leaders in improving the quality of package pursuing education, (2) the quality of tutors in the package pursuing education program, (3) the quality of service to citizens learning in the package pursuing education program, and (4) satisfaction customers on a package pursuit education program. The research design used is a multi-site study, which means combining several different sites, subjects, settings and places of events, namely the Community Learning Activity Center (PKBM). Maju Jaya. Arifin (1996) explained that a multi-site research design is when the researcher examines two or three or more subjects who have different settings. Furthermore, Bogdan and Biklen (1992) multi-site study design was chosen because the two research sites have a closeness or typology similarity that allows researchers to develop substantive theories. The presence of researchers in the field is that researchers act as instruments as well as data collectors. Researchers will carry out a visit to Community Learning Activity Center (PKBM), Research on the implementation of total quality management in the package pursuit program will be carried out at Community Learning Activity Center (PKBM).

The main data used in the study of the implementation of total quality management is the head or leader of the two institutions pursuing education as a key informant and supporting informants in obtaining research data, supporting informants in this study are teaching staff and students in the institution. In qualitative research, informants play an important role. Data collection techniques in the form of participant observation, in-depth interviews, and documentation. The data analysis of this research is cross-site data analysis. The data validity test in this research is in the form of credibility, confirmability, and triangulation tests. The stages of research are the formulation of main research ideas, consultations with supervisors, research proposal seminars, the management of research permits, research in the field, data processing, and examinations.

\section{Quality of Tutors in Pursuing Education Packages}

\section{Site I}

Tutor quality can be seen from the competency standard and tutor qualification. Tutor competency standards in PKBM Maju Jaya seen from the four averages get good grades from the assessment of the leadership of the institution. Judging from the tutor qualification standards at Community Learning Activity Center (PKBM). Maju Jaya, all graduates are from the undergraduate level and teach subjects by tutors' graduates in vocational education packages at PKBM Maju Jaya. The form of implementing good competency standards is that tutors can create an enthusiastic power of citizens learning in the teaching and learning process in the classroom. Comfortable conditions in the classroom created by the tutor become more valuable so that citizens learn enthusiastically in learning.

\section{Site II}

The quality of tutors at Community Learning Activity Center (PKBM). Maju Jaya in pursuing education packages based on qualification and competency standards can be said to be good. In terms of the standards for pursuing education tutors the qualification package at PKBM Maju Jaya has fulfilled the views of the 26 tutors who are all undergraduate graduates and teach according to scientific field qualifications. In terms of the competency of pursuing education tutors, the package at Community Learning Activity Center (PKBM). Maju Jaya can be said to be fulfilling from the social aspect, where the tutor prioritizes the closeness with the citizens of learning to aim to help the process of good learning.

\section{Quality of Service in Pursuing Education Packages}

\section{Site I}

The quality of pursuing education services in the Community Learning Activity Center (PKBM). Maju Jayakepada residents can be said to be good learning, although there must be some improvements and additions in terms of facilities. Learning services are things that need to be improved because they are closely related to the quality of tutors' services in teaching citizens' learning, which of course has an influence on the achievement and motivation of citizens to pursue package learning. Administrative services must also be able to accommodate all the learning needs of citizens, both information and ease in completing administrative requirements needed in the process of pursuing education packages. Learning facility services in the pursuit of education package at Community Learning Activity Center (PKBM). 
Maju Jay can be said to be adequate because in terms of the availability of devices already fulfilling, such as LCDs, laptops, computers, desks, and chairs which are the core devices in the learning process in class, so learning in class can run well.

\section{Site II}

The quality of service at Community Learning Activity Center (PKBM). Maju Jaya can be said to be already good, considering that Community Learning Activity Center (PKBM). which is a social institution already has programs in developing the quality of learning citizens. This is evidence of the seriousness of the Community Learning Activity Center (PKBM). in providing quality human resources through package education. Services at Community Learning Activity Center (PKBM). Maju Jaya consists of three aspects of service, namely services for developing citizens' learning abilities, learning services, and teaching support services. Of the three aspects do have important things in improving the quality of education, especially in the pursuit of education packages.

\section{Learning Citizens Satisfaction in Pursuing Education Packages}

Site I

The level of satisfaction of citizens learning to pursue education packages in the Community Learning Activity Center (PKBM). Maju Jayamalam experiencing a high level of satisfaction. Judging from the learning services, citizens learn to experience the ease of receiving material from tutors, then residents learn to feel comfortable in communicating with tutors, so the learning process becomes smooth and good. From administrative services as well as citizens learn to find ease in administrative matters, moreover, the cost of pursuing education packages is also easy to reach. Likewise, with the learning facility services, learning residents feel they have received good services, such as the availability of learning support facilities. Although there are some things that people want to learn so that there is an increase in services by the Community Learning Activity Center (PKBM) Bintang Bangsa.

\section{Site II}

The satisfaction of learning citizens in the Community Learning Activity Center (PKBM). Maju Jaya is carried out in three services, namely teaching services, teaching support services and learning capacity development services. The satisfaction of learning citizens towards the three services provided by the Community Learning Activity Center (PKBM). in the pursuing education program package can be said that the learning residents have quite high satisfaction. That is because some services are felt by the learning community not to be provided by PKBM in the pursuit of education services package, so there is an expectation that learning citizens cannot be met by the Community Learning Activity Center (PKBM). as the provider of pursuing education and service providers.

\section{DISCUSSION}

The Role of Leaders in Improving the Quality of Pursuing Packages

The role of the leadership in improving the quality of the institution at its leadership cannot be far from the vision and mission the leader wants to achieve in improving the quality of the institution. Sallis (2011: 174) states that there are eleven leadership roles in realizing integrated quality management in the world. Of these eleven roles, some roles have synchronization in the implementation of leadership roles in improving the quality of package pursuit education in the Community Learning Activity Center (PKBM). Maju Jaya. The role as stated by Sallis (2011) is having an integrated vision for the institution, leading innovation in the institution, directing employee development, having a commitment to remove both organizational and cultural barriers, and developing appropriate mechanisms to monitor and evaluate success.

In Community Learning Activity Center (PKBM). Maju Jaya seen from the vision's role the leadership of this institution plays the role of its vision more towards serving customers, in this case, are learning citizens who are still unable to receive education at the formal education level. The leadership of this institution has the intention to serve all people in enjoying educational services.

In implementing the vision and mission of the institution, the leader must, of course, carry out several roles to achieve this. The first role carried out is the role of leadership in managing this institution in terms of operational in general and financially, this is an important role of leadership in improving the quality of the pursuit education package in the Community Learning Activity Center (PKBM). it leads, seeing Community Learning Activity Center (PKBM). is a non-governmental organization that has no ties with the government and is independent. So that the leadership role in terms of operational and financial management is needed to maintain the smoothness of the learning process of pursuing education. 
The second role that was carried out was the role of the Community Learning Activity Center (PKBM). Maju Jaya leader in promoting this institution to the community. The mechanism can vary in promotion, namely through information technology media (website) or the leadership of the institution to collaborate with the parties concerned. The direct collaboration mechanism of the leadership is through cooperation with the village officials that are around the institute of the pursuit of education package, this method turns out to be more effective than the way through information technology media.

The next role that is no less important is the role of the leader in creating a comfortable atmosphere and being able to socialize with all parts of the institution. An example of a simple leadership must understand what institutional conditions and be able to control all problems that occur in the institution by involving all elements of the institution in solving it. In addition, the leader must be able to analyze the needs of his institution, for example, the need to improve the quality of tutors. There are several mechanisms, one of which is that leaders often include tutors in training of teaching staff. A process is a form of leadership concern for employees to improve the quality of employees Furthermore, the role of the leader in the role of supervision of the institution, either to the tutor or to the learning population.

Tutor supervision is carried out through the performance appraisal conducted by the leader, so that the leader will understand the conditions and the development of the tutor in his institution, as well as being a medium for indicators of improving the quality of tutors at the institution. Supervision of learning citizens carried out to measure how satisfied learning citizens are with the services provided by the institution so that the leader can know all the needs needed by citizens to learn in the future.

The findings of the PKBM Maju Jaya show that the role of the leadership of the institution leads to the leader as the facilitator of the foundation's policies, in this case, the president director of Community Learning Activity Center (PKBM). Maju Jaya. Also, the leadership of Maju Jaya's Community Learning Activity Center (PKBM). Positioned itself as an innovator in several programs to advance the pursuit education package at the PKBM that he leads. Then the leader also positioned himself as a supervisor of all the activities in the Community Learning Activity Center (PKBM). Maju Jaya in the implementation of the chase education package.

In line with the findings of the two educational institutions pursuing the package regarding the role of the leader of Usman (2008: 272) states the role of an educational leader is as an educator, manager, administrator, supervisor, social, leader, entrepreneur, and climate.

From the research findings above it can be concluded that the role of leadership in improving the quality of education is very influential. Especially the role of leaders as leaders, supervisors, innovators, and leaders can control and create an atmosphere that is conducive and comfortable.

\section{CUSHION}

\section{The Role of Leaders in Improving the Quality of Pursuing Packages. Quality of Tutors in Pursuing Education Packages}

The quality of the teaching staff at the pursuing educational institutions is based on the qualification standards and the competency standards of the educators listed in Permendiknas No. 16 of 2007 article 1 Paragraphs 1 and 2. By the tasks they carry out, tutors must also have the qualifications and abilities appropriate to the field of learning. which it carries.

The findings in the field of qualification standards at the two institutions have in common, both Maju Jaya Community Learning Activity Center (PKBM). and Maju Jaya Community Learning Activity Center (PKBM). consist of tutors who are graduates of undergraduate education (S1), and teach according to the knowledge of undergraduate tutor education. Then the tutor must also be able to condition the class during the learning process in class and carry out a smooth communication between the tutor and the citizens learning while learning in class. In line with the findings Rizal (2009) provides a picture that is in line with research findings regarding tutor qualification standards, states that the tutor's requirements are to have a diploma from an Educational Personnel Education Institution (LPTK), master the substance of the material being taught, be able to manage learning activities in the classroom and master the learning activities in the classroom and master participatory learning techniques.

Tutor competency standards following research findings on the two Community Learning Activity Center (PKBM). have a slight difference. At Community Learning Activity Center (PKBM). Maju Jaya the standard of competence of the tutor uses several aspects of competence, such as andragogic competence where the tutor instills education to adults, personality competence where the tutor provides examples of behavior in the classroom or outside the classroom, social competencies, for example, tutors view citizens as friends and professional competence, tutors have loyalty in teaching. This is in line with PP No. 19 of 2005 which reads the standard "The minimum competency of a tutor is personality, andragogic, professional and social competencies. Meanwhile, the findings of the Community Learning Activity Center (PKBM). Maju Jaya tutor competency standards were applied more dominantly to the social competencies of the tutors, there are several backgrounds, such as the condition of young learning residents and their willingness to be very high, so that tutors must use the nature of openness in 
communicating with citizens of higher learning. From this incident, other competencies are not so dominantly implemented by tutors when teaching in class, it can be said to be a complement to social competencies.

From some of the research findings discussed above, it can be concluded that the qualification standards of the two institutions meet the qualifications of graduates and the burden of subjects carried by the tutor by the educational background of the tutor. Then, the competency standards of the two institutions have a slight difference in the implementation of tutor competencies. In the first institution, the application of competency standards is more comprehensive than every aspect of competency standards, while the second institution of application is more dominant in only one aspect of competency standards. However, in essence, the tutor can be said to be of quality if it can fulfill the personal, andragogic, social and professional competencies in carrying out their duties and obligations.

\section{Quality Education Services Pursue Packages}

Educational services are the main thing in assessing whether or not the quality of an education provider. This condition occurs because educational services are aspects that are directly related to students, while students are the main target of educational services in an institution.

The definition of service quality is centered on efforts to meet the needs and desires of customers and the accuracy of their delivery to meet customer expectations. According to Tjiptono and Diana (2003), service quality is the expected level of excellence and control over the level of excellence is to meet customer desires. In line with the theory, the findings of the study in the first Community Learning Activity Center (PKBM). about the quality of the pursuit education service package illustrate that the services provided by PKBM to learning citizens can be said to be of good quality. Services provided to learning citizens in the form of learning services, administrative services, and learning facility services are all targeted at learning citizens. It shows that Community Learning Activity Center (PKBM) Maju Jayam provides education services to meet the educational needs of customers, in this case, are learning citizens.

Research findings in the second institution show that they are not too different from the first institution, namely that the services provided so far have focused on meeting the needs of learning citizens. The form of service that has been provided so far has been in the form of learning services, development services for the ability to learn citizens to prepare citizens to learn in the face of competition and administrative services. All of these services show that services in the second institution focus on meeting customer needs.

From the findings of the two institutions regarding the quality of education services in the pursuit of a package, there are some general and specific similarities as well as differences in some learning service programs. The general similarity of services in both institutions focuses on meeting the needs of learning citizens in pursuing education in the Community Learning Activity Center (PKBM). provider of the pursuit of education package. The similarity, in particular, is that the two institutions also provide administrative services to the learning community. The difference that is seen is that the two institutions have their priority services, namely service-learning servants to meet the learning needs of pursuing education packages, while the second institution prioritizes service development for learning citizens through training in developing student skills, in the form of entrepreneurship, culinary, fashion and automotive training to learning citizens.

\section{Citizens Satisfaction Learning Education Pursue Package}

Education customer satisfaction or learning citizens are part of the indicators of good education implementation because with customer satisfaction it can be seen that an institution can provide satisfactory services to learning citizens. Also, the benefit of measuring customer satisfaction is that the institution will have a benchmark against the condition of the institution as seen from the response of the citizens' learning satisfaction.

From the findings of the research at the first institution, it is known that the measurement of customer satisfaction is carried out in just a few periods and uses a survey method to learning citizens through question sheets. This is in line with Kotler (1999) which states that there are several ways in which agencies measure customer satisfaction, namely compliant and suggestion systems (customer complaints and service satisfaction) surveys (customer satisfaction surveys). Meanwhile, the findings of the second institution use the complaints and suggestions method. This is indicated by the institution measuring customer satisfaction through satisfaction evaluations at the end of each school year and the mailbox in delivering its satisfaction.

Success in measuring customer satisfaction will produce an outcome that will be useful for each institution. The benefits obtained by the institution in the form, the institution will improve the quality of the institution on an ongoing basis, making attention to learning citizens a priority, motivates tutors to be more qualified and makes it easier for institutions to show the level of satisfaction of learning citizens to related parties both the education office or the supervisory institution in the world of education. 
The level of satisfaction of learning citizens on the findings of the first site shows that the level of satisfaction of learning citizens towards the services provided. These services consist of learning services, administrative services, and learning facility services. Of the three services, the learning community feels fulfilled, because basically, the learning needs of the citizens in the process of pursuing a training package are the services provided by the provider of the pursuit of education program according to or not by the wishes or expectations of the learning community. So the fulfillment of the expectations of learning citizens is the most important thing if the satisfaction of learning citizens is realized. Aritonang (2005) states that there are two measures of customer satisfaction, namely customer expectations that serve as a comparison of a measure and customer satisfaction associated with product performance. Seeing from this opinion the expectations of citizens learning on the first site can be said to have been running because what residents want to learn institutions already provide these services.

Not much different from the first sight, the interest of learning citizens on the second site on the services provided by the institution also meets the expectations of learning citizens. As with teaching services, residents learn to feel comfortable in the learning process in the classroom because their tutors are easy to communicate with and provide services in the form of learning capacity development, it makes learning citizens feel helped in preparing their abilities to face competition in looking for work. These conditions indicate that the expectations of learning citizens have been able to be fulfilled by the institution and learning citizens are also enthusiastic in participating in every activity provided by the institution. Although there are still some things that need to be added in providing services to learning citizens. For example the availability of teaching support tools (LCD and laptop) that still do not exist.

Customer satisfaction or learning citizens at both sites can be concluded that they have met satisfying criteria, because in terms of fulfilling the expectations of learning citizens both institutions have realized through the provision of services and learning residents feel fulfilled in terms of their expectations. Although several things must be added by the institution in terms of meeting the needs of learning citizens.

\section{CONCLUSIONS AND SUGGESTIONS}

\section{Conclusion}

The roles of leaders in both institutions have their characteristics, on the first site, the leaders play a total role in playing their roles, while at the second site the leaders are more coordinating with foundations. The quality of tutors on both sites viewed from qualification standards can be said to have met, while viewed from the tutor competency standards both institutions have implemented aspects of teacher competency. In terms of service quality the first site provides services in the form of learning services, administration and learning facilities, for the second site provides services in the form of teaching services, teaching support services and learning capacity development services. The satisfaction of learning citizens at the two sites shows a fairly high level of satisfaction seen from the perceptions of citizens learning, although there are some things that the desires of learning citizens have not been fulfilled.

\section{The Chairperson of the Institute for Pursuing Education Package}

For the leader of the package pursuing education provider, it is expected to further enhance its role as the highest shooter in improving the quality of package pursuing education and as a pioneer in improving package pursuing education services. So that the quality of pursuing education packages is equivalent to general education.

\section{The Chairperson of the Institute for Pursuing Education Package}

For the leader of the package pursuing education provider, it is expected to further enhance its role as the highest shooter in improving the quality of package pursuing education and as a pioneer in improving package pursuing education services. So that the quality of pursuing education packages is equivalent to general education.

\section{Other Researchers}

Hopefully, this research will be the subject of the next research study and be able to inspire other researchers to study more deeply on integrated quality management in general and pursue education in particular.

\section{REFERENCES}

1. Alt W, LOHRER H, GOLLHOFER A. Functional Properties of additional ankle taping: neuromuscular and mechanical effects before and after exercise. Foot Ankle Int. 1999; 20:238245.

2. AGNEW PS. Taping of the foot and ankle for Korean karate. J Am Podiatr Med Assoc. 1993; 83:534-6. 
3. Arikunto, Suharsimi.2002. Dasar-Dasar Evaluasi pendidikan. Jakarta : PT. Rineka Cipta.

4. Arikunto, Suharsimi.2006.Prosedur Penelitian Suatu Pendekatan Praktik, edisi Revisi VI. Jakarta PT.Rineka Cipta.

5. Balai Pengembangan Kegiatan Belajar.2001. Pengelolaan PKBM. Jakarta: Dirjen Pendidikan Luar Sekolah

6. Bodgan dan Taylor.1975.Methodology pendidikan. Bandung: CV. Aria Duta.

7. Cambel, Earl.1989.Management Organisation.USA:Routledge.

8. Daft, Richard L. 2002. Manajemen Edisi Kelima Jilid Satu. Jakarta : Erlangga.

9. Depdikbud.1977.Pedoman pelaksanaan pengawasan di Lingkungan Depdikbud. Bengkulu.Kanwil Depdikbud : Bengkulu

10. Undang-Undang No. 20 Tahun 2003 Tentang Sistem Pendidikan Nasional. Jakarta: Dirjen Didasmen.

11. Depdiknas.2005.Peraturan prmerintah Republik indonesia Nomor 19 tentang standar pendidikan nasional. Jakarta: Dirjen Didasmen

12. Dinas Pendidikan Provinsi Jawa Timur. 2000. Informasi Ringkas Tentang Pusat Kegiatan

13. Belajar Masyarakat (PKBM). Bandung: CV. Aria Duta.

14. Djuju, Sudjana.2000.Manajemen Program Pendidikan untuk Pendidikan Luar Sekolah dan Pengembangan Sumber Daya Manusia. Bandung: Fallah Production.

15. Fasli, R.2001.Peningkatan Kemampuan Pusat Kegiatan Belajar Masyarakat (PKBM). Yogyakarta: UNY Press.

16. Gie,John.1982.Manajemen Sumber Daya Manusia, Edisi Bahasa Indonesia. Jakarta : PT. RajaGrafindo Persada.

17. Handoko, T Hani. 2003. Manajemen. Yogyakarta: BPFE Yogyakarta.

18. John, Friedmann. 1979. Urban Proverti in Latin America. Development Dialogue, Volume 1 April 1979. Upsala: Dag Mammeskjold Foundation.

19. Kamil, Mustofa.2009. Pendidikan Nonformal.Bandung: Alfabeta

20. Komar, Oong. 2004. Model Pengembangan Kelompok Belajar Usaha Berbasis Unit Usaha Kecil. Jurnal Sosiohumaniora, Volume 4 No.2 Juli 2004

21. Lincoln, Yvonna S. \& Egon, Guba. 1985. Naturalistic Inquiry. London: Sage Publication.

22. Lird \& Lird. 1970. Practical and Bussines Phychology. Dikutip dan diterjemahkan oleh Leila Chairani Budiman. Atikel Disiplin dalam pembangunan (pembangunan psychology).

23. ___ Lexy. 2006. Metodologi penelitian Kualitatif. Bandung: PT Remaja Rosdakarya

24. Ardy. 2012. Manajemen Pendidikan Karakter: Konsep dan Implementasinya di Sekolah. Yogyakarta: PT Pustaka Insan Mada

25. Yulaellawati, Ella.2011.Panduan standar keefektifan dan prosedur penyelenggaraan pusat kegiatan belajar masyarakat (PKBM): Jakarta.

26. Zuriah, Nurul.2007. Pendidikan Moral dan Budi Pekerti Dalam Prespektif Perubahan: Menggagas Platform Pendidikan Budi Pekerti Secara Kontekstual dan Futuristik. Jakarta: Bumi Aksara.

27. Pengelolaan Pusat Kegiatan Belajar Masyarakat (PKBM). Bengkulu: Universitas Bengkulu.

28. Mulyono,D.(2018). The Strategy of Managers in Moving Businss Learnning Group Programin PKBM Srikandi Cimahi City.JEE,1(1),37-38

29. M. Ihsan Dacholfany, Peranan Pengambilan Keputusan Dalam Rangka Menciptakan Inovasi Di Bidang Pendidikan, Jurnal Dewantara Vol. I , No . 01 Januari - Juni 2016.

30. M. Ihsan Dacholfany, Pemberdayaan Masyarakat Dalam Meningkatkan Mutu Pendidikan Non Formal Di Metro Lampung (Studi Kasus Pkbm Al-Suroya), TAPIS, Vol. 02, No. 1 Januari Juni 2018

31. Nasution, Mulia.1995.Metode Research Penelitian Ilmiah.Jakarta: Bumi Aksara

32. Nasution, Mulia, S.E. 1998.Manajemen Personalia.Jakarta: Penerbit Djambatan

33. Septiani. 2016. Pengalaman Pusat Kegiatan Belajar Masyarakat (PKBM) dalam Memfasilitasi Masyarakat Belajar Sepanjang Hayat. Jurnal Ilmiah VISI PPTK PAUDNI, 10 (2), 67-76 journal.unj.ac.id/jurnalfip/index.php/visi/article/download/13/16, diakses tanggal 13 Januari 2018 
34. Sihombing, Umberto.1999. Pendidikan Luar Sekolah: Kini dan Masa Depan. Jakarta: PD. Mahkota.

35. Sihombing, Umbertus.2000. Pendidikan Luar Sekolah, Manajemen Strategi:Konsep, Kiat dan Pelaksanaan. Jakarta: PD. Mahkota.

36. Stoner,James,A.F.1996.Manajemen,Edisi Bahasa Indonesia. Jakarta: PT.Prenhallindo.

37. Sudjana,Djudju.2003.Manajemen Program Pendidikan (Untuk Pendidikan Nonformal dan Pengembangan SDM).Bandung:Falah Production.

38. Sugiyono.2009. Metode Penelitian Pendidikan: Pendekatan Kuantitatif, Kualitatif, dan R\&D. Bandung: Alfabeta.

39. Sugiyono, 2012.Metodologi Penelitian Kuantitatif. Bandung: PT Alfa Beta.

40. Sutisna, D.F, Sinaga, D dan Rosfiantika, E. 2012. Peranan PKBM dalam Menumbuhkan Minat Baca Warga Belajar. [Online]. eJurnal Mahasiswa Universitas Padjadjaran, Volume 1 N0. 1, 2012, hal. $1-17$. Tersedia http://download.portalgaruda.org/article.php?article=103525\&val=137

41. Sukmadinata.2003.Landasan Psikologi Proses Pendidikan.Bandung: Remaja Rosakarya

42. Surakhmad.1980.Dokumentasi. Bandung:Alfabeta

43. Terry, George R dan Leslie W Rue.2005. Dasar - Dasar Manajemen. Jakarta :Bumi Aksara.

44. Ukas, M.1993.Manajemem Pendidikan.Bandung:Alphabeta.

45. Winarno, Surakhmad, 1980. Pengantar Penelitian Ilmiah..Bandung : Tarsito

46. Widhiya Ninsiana and M.Ihsan Dacholfany, Reorientation of Islamic Higher Education Leaders in Dealing With The Global World, Journal Al-Ulum Volume 17 Number2 December2017 Page $332-351$ 